\title{
ФОРМУВАННЯ ДИНАМІЧНОЇ ПІДСИСТЕМИ АНТИКОРУПЦІЙНОЇ СИСТЕМИ В УКРАЇНI: ТЕОРЕТИКО-ПРАВОВІ АСПЕКТИ
}

Білик I. B.

Стаття присвячена дослідженню теоретико-правових аспектів формування динамічної підсистеми антикорупційної системи в Україні, яка охоплює функціональну й комунікативну підсистеми. Доведено, що функціональна підсистема антикорупційної системи охоплює правотворчість, правореалізацію і правозастосування. У сфері правотворчості формування антикорупційної системи призводить до низки змін, серед них - активізація правотворчого процесу, результатом якого є прийняття антикорупційного законодавства; ратифікація міжнародних і європейських стандартів у сфері запобігання i протидії корупціі; зростання впливу міжнародних і європейських інституцій, діяльність яких спрямована на боротьбу з корупцією, на антикорупційну систему в Україні; розширення кола й змісту зобов'язань у сфері протидії корупції, взятих на себе Україною у межах участі в антикорупційних правових актах і органах; зростання ролі й значення модельних законів у сфері протидії корупиіі; еволюція традиційних правових понять та інститутів, безпосередньо пов'язаних із запобіганням і протидією корупції; зростання впливу громадськості на антикорупційну правотворчу діяльність.

Підписання «Угоди про асоціацію» окреслило основні принципи й положення щодо антикорупційної діяльності які, своєю чергою, формують теоретико-правові засади правотворчості й правозастосування як складників функціональної підсистеми антикорупційної системи в Украӥні. В «Угоді про асоціацію» боротьба 3 корупцією визнається як: спільна цінність ЄC, імпліцитно пов'язана з демократією, повагою до прав людини і основоположних свобод та верховенством права; важливий складник і принцип вільної ринкової економіки; напрям співпраці у сфері юстиції, свободи та безпеки; напрям діяльності щодо імплементації відповідних міжнародних стандартів у національне право й законодавство; напрям двостороннього, регіонального та міжнародного співробітництва, обміну найкращими практиками; обмін інформацією відповідно до наявних правил. Таким чином, формування антикорупційної системи в Україні посилює правові взаємозв'язки і взаємозалежності, спричиняє процеси адаптації, уніфікаціі, імплементаціі, гармонізації правових принципів і норм, що мають антикорупційну спрямованість.

Ключові слова: антикорупційна система, антикорупційне законодавство, динамічна підсистема, зако- нотворчість, корупція, правотворчість, правозастосування, функціональна підсистема антикорупційної системи.

Bilyk I. V. Formation of a dynamic sub-system of the anti-corruption system in Ukraine: theoreticallegal aspects

The article is devoted to the study of theoretical and legal aspects of the formation of a dynamic subsystem of the anti-corruption system in Ukraine, which covers the functional and communication subsystems. It is proved that the functional subsystem of the anti-corruption system covers law-making, law enforcement and law enforcement. In the field of law-making, the formation of the anticorruption system leads to a number of changes, including: intensification of the law-making process, the result of which is the adoption of anti-corruption legislation; ratification of international and European standards in the field of preventing and combating corruption; growing influence of international and European institutions, whose activities are aimed at combating corruption on the anti-corruption system in Ukraine; expanding the scope and content of anti-corruption commitments made by Ukraine in the framework of participation inanti-corruption legal acts and bodies; growing role and importance of model laws in the field of anti-corruption; evolution of traditional legal concepts and institutions directly related to preventing and combating corruption; growing public influence on anti-corruption law-making.

The signing of the Association Agreement outlined the basic principles and provisions for anti-corruption activities, which, in turn, form the theoretical and legal foundations of law-making and law enforcement as components of the functional subsystem of the anticorruption system in Ukraine. The Association Agreement recognizes the fight against corruption as: a common EU value implicit in democracy, respect for human rights and fundamental freedoms, and the rule of law; an important component and principle of a free market economy; direction of cooperation in the field of justice, freedom and security; direction of activity on implementation of relevant international standards into national law and legislation; direction of bilateral, regional and international cooperation, exchange of best practices; exchange of information in accordance with existing

() Білик І. В., 2020 
rules. Thus, the formation of the anti-corruption system in Ukraine strengthens legal ties and interdependencies, causes the processes of adaptation, unification, implementation, harmonization of legal principles and norms that have an anti-corruption orientation.

Key words: anti-corruption system, anti-corruption legislation, dynamic subsystem, law-making, corruption, law enforcement, functional subsystem of anti-corruption system.

Постановка проблеми та іï актуальність. Євроінтеграційна спрямованість правового розвитку України вимагає від неї як прийняття важливих антикорупційних нормативно-правових актів, так і відповідної ефективної правозастосовної діяльності. Відсутність реальних результатів у напрямі запобігання й протидії корупції унеможливлює євроінтеграційний поступ України.

Упродовж 2019 року підтримані Верховною Радою України IX скликання законодавчі ініціативи Президента у сфері протидії корупції уможливили розблокування діяльності новоствореного Вищого антикорупційного суду України, забезпечили перезапуск роботи НАЗК, повернули кримінальну відповідальність за незаконне збагачення та запровадили нову процедуру цивільної конфіскації необґрунтованих активів публічних службовців. Важливими у цьому напрямі стали й заходи щодо посилення захисту викривачів корупції, усунення окремих обмежень для проведення ефективного досудового розслідування кримінальних правопорушень. Водночас 27 жовтня 2020 року Конституційний Суд України ухвалив Рішення № 13-р/2020 у справі № 1-24/2020(393/20) щодо конституційності окремих положень Закону України «Про запобігання корупції», Кримінального кодексу України, яким визнав такими, що не відповідають Конституції України ( $\epsilon$ неконституційними): пункти 6, 8 частини першої статті 11, пункти 1, 2, 6-101, 12, 121 частини першої, частини другу-п'яту статті 12, частину другу статті 13, частину другу статті 131 , статтю 35, абзаци другий, третій частини першої статті 47, статті 48-51, частини другу, третю статті 52, статтю 65 Закону України «Про запобігання корупції» від 14 жовтня 2014 року № 1700-VII зі змінами; статтю 3661 Кримінального кодексу України.

Суперечливий характер рішення КСУ викликав хвилю обурення з боку науковців, політиків, громадськості та звинувачень суддів КСУ у згортанні антикорупційної діяльності в Україні. Зазначене у поєднанні $з$ відсутністю реальних результатів боротьби з корупцією свідчить про те, що, попри важливі антикорупційні заходи в Україні, не були вирішені найбільш важливі проблеми у сфері запобігання i протидії корупції, здебільшого запроваджуваним змінам на рівні законотворчому та правозастосовному бракувало системно-структурного й функціонального підходів.

Отже, актуальність наукового осмислення формування антикорупційної системи в Україні, з огляду на її практичну значимість, не викликає сумнівів та викликала жвавий науковий інтерес у вітчизняній юридичній науці.

Аналіз останніх досліджень і публікацій. У сучасній вітчизняній правовій доктрині антикорупційна проблематика посідає чільне місце насамперед з огляду на ії значну затребуваність вітчизняним досвідом і практикою протидії корупції. Антикорупційній тематиці присвячені праці відомих українських учених, таких як: М. Бакай, Я. Барназюк, В. Баштанник, К. Бердніков, М. Білинська, Ю. Битяк, О. Бусол, Д. Гарбазей, Т. Василевська, В. Василенко, І. Голосніченко, О. Дудоров, М. Камлик, В. Коваленко, Т. Коломоєць, Ю. Ковбасюк, О. Колб, С. Лазаренко, М. Мельник, $Є$. Невмержицький, А. Онуфрієнко, Я. Пилип, С. Серьогін, О. Скрипнюк, В. Федоренко, В. Шакун та ін. Водночас теоретико-правові аспекти проблем запобігання й протидії корупції лише впродовж останніх років стали предметом дослідження вчених, зокрема, таких як Л. Удовика, О. Макаренков та ін. Проте загальнотеоретичні положення формування динамічної підсистеми антикорупційної системи в Україні залишаються не досить повно розкритими.

Методологічним підґрунтям дослідження $\epsilon$ діалектичний, системний, структурний і функціональний методи, які у своїй сукупності та взаємодоповнюваності спрямовують до аналізу динамічної підсистеми антикорупційної системи в Україні. Так, згідно з положеннями системно-структурного підходу антикорупційна система складається із низки компонентів і елементів, які умовно можна об'єднати у п'ять підсистем [1]: інституційну (суб'єкти антикорупційної діяльності), ідеологічну (антикорупційна політика, правова культура, правова свідомість), нормативну (антикорупційний складник системи права й законодавства), функціональну (антикорупційна правотворча й правозастосовна діяльність), комунікативну (зв'язки між підсистемами, компонентами, елементами антикорупційної системи). Якщо інституційна, ідеологічна й нормативна підсистеми умовно формують статичну систему вищого рівня, то функціональна й комунікативна підсистеми об'єднуються в динамічну систему. 
Ґрунтуючись на системному й функціональному методах дослідження, функціональна підсистема антикорупційної системи постає як система нижчого рівня стосовно антикорупційної системи загалом, охоплює правотворчу, правореалізаційну й правозастосовну діяльність. У кожній із зазначених підсистем різною мірою втілюються напрями, види і форми антикорупційної діяльності. До уваги необхідно взяти методологічно важливе положення, згідно з яким ефективність функціонування системи залежить як від наявності компонентів і елементів системи, так і від належних функціональних зв'язків між ними. Саме тому функціональний аспект антикорупційної системи відіграє велике значення у досягненні кінцевої мети системи - ефективній протидії та відсутності корупції в країні. Обмежений обсяг роботи дозволяє зупинитися на найбільш важливих антикорупційних аспектах правотворчості, правореалізації й правозастосування.

Мета статті - розкрити теоретико-правові аспекти формування динамічної підсистеми антикорупційної системи в Україні.

Виклад основного матеріалу. Функціональна підсистема антикорупційної системи втілюється у низці напрямів і форм діяльності антикорупційних органів. Правові й організаційні форми й напрями антикорупційної діяльності відповідних суб'єктів у державі, яка дотримується принципу верховенства права, неможливі без належної антикорупційної правотворчої діяльності, яка закладає правове підґрунтя такої діяльності, визначає їі напрями, зміст, форми та чітко окреслює суб'єктів такої діяльності. Тому саме антикорупційна правотворча діяльність $\epsilon$ первинною стосовно інших форм і видів антикорупційної діяльності та закладає правове підґрунтя для них.

У загальній теорії права правотворчість розглядається як діяльність державних органів і посадових осіб з ухвалення, зміни, скасування юридичних норм. У розумінні змісту правотворчості на увагу заслуговують міркування Л. Удовики, яка зазначає: «Правотворчість постає як атрибутивна форма діяльності держави, що виявляється в активній, творчій діяльності уповноважених суб'єктів чи безпосередньо народу, зумовлена плинними потребами внутрішньодержавного і глобального суспільного розвитку та оновленням нормативно-правової бази, має офіційний, правовий, процесуальний характер і передбачає встановлення вимог справедливості й забезпечення суспільного розвитку у правових формах» [2, c. 266-267].
Антикорупційна правотворча діяльність як складова частина функціональної підсистеми антикорупційної системи безпосередньо пов'язана із законотворчою діяльністю. Потреба в активній і цілеспрямованій антикорупційній правотворчій діяльності в Україні спричинена масштабами і наслідками поширення корупції в країні, які становлять загрозу для суспільного розвитку української держави. Поряд із внутрішньодержавними потребами необхідність і важливість цілеспрямованої антикорупційної діяльності зумовлена глобальними та регіональними потребами, зокрема євроінтеграційними, виконанням Україною взятих на себе зобов'язань. Вже перші кроки України у євроінтеграційному напрямі, відображені зокрема в преамбулі «Угоди про партнерство і співробітництво між Україною і Європейськими Співтовариствами та їх державами-членами», передбачали утвердження спільних цінностей, насамперед таких як верховенство закону, повага до прав людини, створення багатопартійної системи з вільними і демократичними виборами та економічною лібералізацією з метою створення ринкової економіки та «необхідність докладати зусилля i співпрацювати з метою запобігання використання своїх фінансових систем для відмивання доходів, отриманих від кримінальної діяльності загалом» (ст. 68). Утвердження цих цінностей неможливе без протидії корупції [3].

Україна як демократична та правова держава на конституційному рівні визнає принцип примату міжнародного права над національним законодавством. Так, згідно зі статтею 9 Конституції України, міжнародні договори України, згоду на обов'язковість яких дала Верховна Рада України, визнаються частиною національного законодавства України. Окрім базових основоположних міжнародних договорів, Україна $\epsilon$ учасницею значної кількості інших міжнародних і регіональних двосторонніх і багатосторонніх договорів, які стосуються проблем запобігання й протидії корупції. У формі законів України про ратифікацію було імплементовано низку міжнародних угод, конвенцій, підписано низку міждержавних угод, спрямованих на запобігання й протидію корупції.

Цілком закономірно, що на виконання взятих Україною на себе зобов'язань активізувалась правотворча діяльність загалом, у сфері запобігання й протидії корупції зокрема як важливої складової частини євроінтеграційних процесів. У низці документів i нормативно-правових актів, які закладали підґрунтя процесу інтеграції України до Європейського Союзу, визначалися напрями 
й окремі аспекти протидії корупції, серед них Указ Президента України «Про програму інтеграції України до Європейського Союзу» 1998 р. [4, с. 56], Закон України «Про Загальнодержавну програму адаптації законодавства України до законодавства Європейського Союзу» [5], «Програма інтеграції України до Європейського Союзу (2000р.) [6]. Окрім того, з 1998 року для України набрала чинності Європейська конвенція (від 8 листопада 1990 р.) про «відмивання», пошук, арешт та конфіскацію доходів, одержаних злочинним шляхом. Реалізація положень Конвенції потребувала прийняття відповідного Закону «Про запобігання легалізації коштів, здобутих злочинним шляхом».

Результатом активізації правотворчого процесу стало те, що впродовж 2005-2006 рр. в Україні було прийнято низку законів, норми яких спрямовувалися на запобігання й протидію корупції, та відбулася ратифікація міжнародних актів у сфері запобігання й протидії корупції, зокрема було ратифіковано Цивільну конвенцію про боротьбу з корупцією від 4 листопада 1999 (16 березня 2005 р.) [7], Конвенцію Організації Об'єднаних Націй проти корупції від 31 жовтня 2003 р. (18 жовтня 2006 року) [8], Кримінальну конвенцію про боротьбу з корупцією № ETS173 від 27 січня 1999 р. (18 жовтня 2006 р.) [9], Додатковий протокол до Кримінальної конвенції про боротьбу з корупцією від 15 травня 2003 р. № ETS 191 (18 жовтня 2006 р.) [10]. Серед низки зобов' язань і заходів, спрямованих на запобігання й протидію корупції, взятих Україною як державою-учасницею Конвенції ООН, слід виокремити, зокрема:

1) правові: розробляти й здійснювати скоординовану політику протидії корупції за активної участі громадянського суспільства та його інститутів (ст. 5); декларувати доходи і видатки державних службовців (ст. 8); своєчасно формувати і затверджувати національний державний бюджет, забезпечувати державний та громадський контроль за надходженнями і видатками до такого бюджету (ст. 9);

2) організаційно-правові: взаємодіяти з іншими державами, а також міжнародним і регіональним співтовариством у сфері запобігання корупції, розвивати відповідні міжнародні програми і проєкти (ст. 5); створити спеціалізований орган або органи щодо протидії корупції та гарантувати і забезпечувати їх незалежність (ст. 6); створювати прозорі й конкурентні системи державних закупівель, що ґрунтуються на принципах транспарентності, кон- курентності та нетерпимості до корупції (ст. 9); підтримувати та зміцнювати такі системи прийняття на публічну службу, відбору та проходження служби і виходу у відставку невиборних публічних службовців, які ґрунтуються на критеріях бездоганності роботи, справедливості, враховують здібності публічного службовця, а також передбачають спеціальну підготовку корупційно вразливих посадових осіб, їх ротацію та забезпечення гідної винагороди (ст. 7); встановити критерії для відбору кандидатів на публічну службу, які ґрунтуються на засадничих антикорупційних принципах національного права (ст. 7); вживати заходів для посилення чесності та непідкупності суддів і прокурорів з одночасним посиленням їх незалежності (ст. 11); спрощувати адміністративні процедури та забезпечувати їх доступність для громадян (ст. 10); підвищувати стандарти бухгалтерського обліку та аудиту в приватному секторі та встановлювати за потреби цивільно-правові, адміністративні та кримінальноправові санкції за невжиття таких заходів (ст. 12); сприяти співробітництву відповідних правоохоронних органів з юридичними особами приватного права (ст. 12);

3) організаційні: поглиблювати та поширювати у суспільстві знання щодо запобігання та протидії корупції (ст. 6); запроваджувати ефективні освітні та навчальні програми для публічних службовців, спрямовані на підготовку цих осіб до належного та сумлінного виконання функцій держави, забезпечення пріоритетності публічних інтересів над особистими (ст. 7); заохочувати з боку держави, inter alia, непідкупність, чесність та відповідальність своїх державних посадових осіб згідно з принципами національної правової системи, а також застосовувати на публічній службі кодекси і правила доброчесної поведінки (ст. 8); запроваджувати процедури, які дають змогу громадянам та інститутам громадянського суспільства отримувати інформацію про функціонування державної влади і процеси прийняття рішень у державному управлінні, а також забезпечувати громадськість інформацією про корупційні ризики у державному управлінні (ст. 10; 14; 18) вживати належних заходів для сприяння участі окремих громадян і громадянського суспільства загалом, а також інститутів та груп, що діють поза межами державного сектору (NGO), у запобіганні корупції та боротьбі з нею (ст. 13) та ін. Зміни торкнулися таких іï форм, як оперативно-виконавча, правоохоронна, і правосуддя.

Примат міжнародного права над національним, підписання міжнародних i європейських 
угод у сфері запобігання й протидії корупції спричинило процеси уніфікації, імплементації, гармонізації правових принципів і норм, що мають антикорупційну спрямованість, тобто правових стандартів протидії корупції. «Збільшення питомої ваги міжнародно-правового масиву в національному законодавстві певною мірою зумовлене тим, що значна частина цих норм діє на випередження, а галузі й інститути міжнародного права виникають значно раніше, ніж відповідні нові галузі й інститути національного права» [2, с. 269]. Міжнародні та європейські правові стандарти існують у формі стандартів-принципів і стандартів-норм. Так, Б. Кофман міжнародні стандарти тлумачить як сукупність зазначених спочатку на міжнародному, а потім і на внутрішньодержавному рівні правових норм і нормативних вимог, що мають різну правову силу, в яких узагальнено накопичений світовим співтовариством держав досвід нормативно-правової регламентації і регулювання певних суспільних відносин [11, с. 7-8, 16]. В узагальненому вигляді під міжнародними стандартами у сфері запобігання та протидії корупції вчені й експерти розуміють систему загальновизнаних принципів і норм міжнародного права, універсальних і регіональних міжнародних договорів, також положень, вимог та рекомендацій, розроблених державами і міжнародними організаціями у сфері боротьби з корупцією та втілених у відповідних міжнародних документах, а також рішення міжнародних судів щодо корупційних деліктів. У сучасній юридичній науці, попри значну увагу вчених до правових стандартів, відсутній вичерпний їх перелік, оскільки їхня кількість постійно зростає, зважаючи на розширення сфер правового регулювання й практику здійснення європейського правосуддя. Окрім того, зміст правових стандартів загалом і у сфері протидії корупції зокрема поглиблюється.

Попри досягнення певного прогресу в законодавчій сфері у напрямі запобігання й протидії корупції, Україні важливо було продовжувати зусилля, спрямовані на боротьбу з корупцією.

Активізація правотворчого процесу у сфері запобігання й протидії корупції чітко простежується у 2014-2015 роках і прийнятті антикорупційного законодавства, насамперед законів України «Про запобігання корупції» від 14 жовтня 2014 р., «Про Національне антикорупційне бюро України» від 14 жовтня 2014 р., «Про засади антикорупційної політики в Україні (Антикорупційна стратегія) на 2014-2017 роки» від 14 жовтня 2014 р., «Про внесення змін до деяких законодавчих актів України у сфері державної антикорупційної полі- тики у зв'язку з виконанням Плану дій щодо лібералізації Європейським Союзом візового режиму для України» від 13 травня 2014 р., «Про внесення змін до деяких законодавчих актів України щодо визначення кінцевих вигодоодержувачів юридичних осіб та публічних діячів» від 14 жовтня 2014 р., «Про державну службу» від 10 грудня 2015 р., «Про службу в органах місцевого самоврядування» від 7 червня 2001 р., «Про очищення влади» від 27 січня 2015 р., «Про Національну поліцію» від 2 липня 2015 р., «Про прокуратуру» від 14 жовтня 2014 р., «Про Національне агентство України з питань виявлення, розшуку та управління активами, одержаними від корупційних та інших злочинів» від 10 листопада 2015 р. та ін. Таким чином, завдяки активізації правотворчої діяльності та прийняття антикорупційного законодавства було сформовано нормативно-правове підґрунтя антикорупційної системи, хоча низка проблем зберігалася, насамперед у сфері застосування антикорупційного законодавства та функціонування новостворених антикорупційних органів.

Поштовхом у формуванні антикорупційної системи в Україні стало підписання «Угоди про асоціацію» [12], у якій запобігання й протидія корупції розглядається спільною цінністю та ключовим елементом, який імпліцитно вплетений у основоположні цінності, на яких побудований Європейський Союз, таких як: демократія, повага до прав людини і основоположних свобод та верховенство права. Окрім того, в документі визначається, що політична асоціація та економічна інтеграція України з Європейським Союзом залежатиме від досягнень України в забезпеченні поваги до спільних цінностей і прогресу в наближенні з ЄС у політичній, економічній та правовій сферах.

Аналіз і узагальнення іiі положень, у яких йдеться про боротьбу з корупцією, дає підстави виокремити декілька основних аспектів, які визначають теоретико-правові засади антикорупційної системи в Україні загалом і динамічної підсистеми зокрема. Зокрема, в «Угоді про асоціацію» боротьба з корупцією визнається: по-перше, спільною цінністю ЄС, імпліцитно пов'язаною з демократією, повагою до прав людини і основоположних свобод та верховенством права (Преамбула, ст. 4); по-друге, важливим складником і принципом вільної ринкової економіки (ст. 3); по-третє, напрямом співпраці у сфері юстиції, свободи та безпеки (ст. 14, 20, 22, 23, 24); по-четверте, напрямом діяльності щодо імплементації відповідних міжнародних стандартів 
у національне право й законодавство (ст. 20, 22, 23, 24); по-п'яте, напрямом двостороннього, регіонального та міжнародного співробітництва на вирішення, inter alia із залученням Європолу, а також обміну найкращими практиками (щодо методик розслідування та криміналістичних досліджень; обміну інформацією відповідно до чинних правил; посилення потенціалу, зокрема, навчання та обміну персоналом; питань, пов'язаних із захистом свідків та жертв) (ст. 22); по-шосте, важливим принципом належного фінансового управління та співробітництва у сфері захисту фінансових інтересів України та ЄС (ст. 459) [12].

Слід зауважити, що в Угоді наголошується на необхідності боротьби з корупцією як у приватному, так і державному секторах (ст.22), та її зв'язок із проблемами тероризму, шахрайства, кримінальної та незаконної організованої чи іншої діяльності, контрабандою товарів тощо. Отже, євроінтеграційна спрямованість правового розвитку України іманентно пов'язана з активізацією правотворчості, формуванням антикорупційного законодавства, ставить нові вимоги у системі формально-юридичних засад антикорупційної діяльності, тобто у системі юридичних принципів, способів, засобів, правил та методів створення, прийняття та введення в дію антикорупційних нормативно-правових актів. Особливого значення набуває модельний закон (міждержавний, міжнародний) як нормативно-правовий документ, що рекомендується державам (у міждержавних співтовариствах) для прийняття як їхнього національного закону і виступає важливим інструментом зближення законодавств. У сфері правотворчості формування антикорупційної системи призводить також до еволюції традиційних правових понять та інститутів, безпосередньо пов'язаних із запобіганням й протидією корупції. Так, упродовж останніх років трансформуються низка понять, серед них, зокрема, такі як: «близькі особи», «антикорупційна експертиза», «громадська антикорупційна експертиза», «антикорупційні програми», «викривачі корупції», «захист викривачів корупції», «конфлікт інтересів», «цивільна конфіскація необґрунтованих активів публічних службовців», «фінансування політичних партій», «фінансова звітність політичних партій».

У розумінні теоретико-правових аспектів формування динамічної підсистеми антикорупційної системи в Україні до уваги необхідно взяти i тенденцію зростання впливу громадськості (української, міжнародної, міжурядової) на антикорупційну правотворчу й правозастосовну діяль- ність. Серед міжнародних органів та інститутів слід виокремити діяльність таких як: ООН, $€ C$, Організація економічного співробітництва i розвитку, Організація Північноатлантичного договору (НАТО), Світова організація торгівлі та інші. Підтвердженням зазначеного $є$ низка ухвалених міжнародних документів, які визначають міжнародні засади участі громадськості у формуванні та реалізації антикорупційної політики [13].

Зростання впливу громадськості на антикорупційну правотворчу діяльність на загальнодержавному рівні здійснюється у межах чітко встановлених правотворчих процедур, спрямоване, головним чином, на встановлення в нормативноправових актах антикорупційних засад у діяльності органів публічної влади шляхом формування приписів загальнообов'язкового характеру, їх зміни, доповнення чи скасування. Так, згідно зі ст. 16 Закону України «Про комітети Верховної Ради України», комітети Верховної Ради України у здійсненні законопроєктної функції зобов'язані: вивчати громадську думку, розглядати звернення громадян, об'єднань громадян, будь-які пропозиції, що свідчать про потребу в прийнятті нових законодавчих актів або у внесенні змін до законодавчих актів, і в разі необхідності готувати відповідні проєкти актів та вносити їх на розгляд Верховної Ради України [14].

Згідно зі встановленими стандартами здійснюється регулювання участі громадськості у формуванні та реалізації державної антикорупційної політики на регіональному та місцевому рівнях. Менш врегульованою на нормативному рівні $\epsilon$ діяльність громадськості на місцевому рівні. Водночас основними засадами їхньої діяльності $\epsilon$ конституційно-правові форми взаємодії територіальних громад з місцевими представницькими органами (зокрема, такі як: місцеві ініціативи, громадські слухання, доручення виборців тощо). Окрім того, важелями впливу $\epsilon$ також встановлення прямих контактів та проведення зустрічей з посадовими і службовими особами органів публічної влади та органів місцевого самоврядування; проведення громадськістю різних публічних заходів (конференцій, форумів, круглих столів) щодо привернення уваги суспільства до проблеми корупції загалом та окремих її проявів зокрема.

Висновки. Здійснений аналіз дає підстави зробити декілька висновків і узагальнень. Динамічна підсистема антикорупційної системи в Україні охоплює функціональну й комунікативну підсистеми. Доведено, що функціональна підсистема 
антикорупційної системи охоплює правотворчість, правореалізацію і правозастосування. Водночас саме у цих сферах зберігаються численні проблеми, які спричиняють розбалансованість антикорупційної системи. У сфері правотворчості формування антикорупційної системи призводить до низки змін, серед них - активізація правотворчого процесу, результатом якого $є$ прийняття антикорупційного законодавства; ратифікація міжнародних і європейських стандартів у сфері запобігання і протидії корупції; зростання впливу міжнародних і європейських інституцій, діяльність яких спрямована на боротьбу з корупцією, на антикорупційну систему в Україні; розширення кола й змісту зобов'язань у сфері протидії корупції, взятих на себе Україною у межах участі в антикорупційних правових актах і органах; зростання ролі й значення модельних законів у сфері протидії корупції; еволюція традиційних правових понять та інститутів, безпосередньо пов'язаних із запобіганням й протидією корупції; зростання впливу громадськості на антикорупційну правотворчу діяльність.

Підписання «Угоди про асоціацію» окреслило основні принципи й положення щодо антикорупційної діяльності, які, своєю чергою, формують теоретико-правові засади правотворчості й правозастосування як складників функціональної підсистеми антикорупційної системи в Україні. В «Угоді про асоціацію» боротьба з корупцією визнається: спільною цінністю ЄС, імпліцитно пов'язаною з демократією, повагою до прав людини і основоположних свобод та верховенством права; важливим складником і принципом вільної ринкової економіки; напрямом співпраці у сфері юстиції, свободи та безпеки; напрямом діяльності щодо імплементації відповідних міжнародних стандартів у національне право й законодавство; напрямом двостороннього, регіонального та міжнародного співробітництва, обміном найкращими практиками; обміном інформацією відповідно до чинних правил. Таким чином, формування антикорупційної системи в Україні посилює правові взаємозв'язки і взаємозалежності, спричиняє процеси адаптації, уніфікації, імплементації, гармонізації правових принципів і норм, що мають антикорупційну спрямованість.

\section{Література}

1. Удовика Л.Г. Антикорупційна складова частина у розвитку правової системи України. Вісник Запорізького національного університету. Юридичні науки : зб. наук. пр. 2020. № 1. С. 180-188.
URL: http://law.journalsofznu.zp.ua/archive/visnik1-2020/28.pdf.

2. Удовика Л.Г. Теоретико-правові засади трансформацій правової системи України в умовах глобалізації : дис. ... д.ю.н. : 12.00.01. Київ, 2014. 473 с.

3. Угода про партнерство і співробітництво між Україною i Європейськими Співтовариствами та ïx державами-членами. Угоду ратифіковано Законом України від 10.11.1994 р. (Втрата чинності від 01.09.2017). URL: https://zakon.rada.gov.ua/laws/ show/998_012\#Text.

4. Про затвердження Стратегії інтеграції України до Європейського Союзу : Указ Президента України від 11. 06. 1998 р. Бюлетень Міністерства юстиції України. 2001. № 3. С. 59-67.

5. Про Загальнодержавну програму адаптації законодавства України до законодавства Європейського Союзу : Закон України від 18.03.2004 р. № 367. Відомості Верховної Ради України. 2004. № 29. Ст. 367.

6. Програма інтеграції України до Європейського Союзу. Програму схвалено Указом Президента № 1072/2000 від 14.09.2000. (Втратила чинність на підставі Указу Президента № 398/2015 від 07.07.2015). URL: https://zakon.rada.gov.ua/laws/ show/n0001100-00\#Text.

7. Цивільна конвенція про боротьбу з корупцією від 4 листопада 1999 р. (ратифікована згідно із Законом України «Про ратифікацію Цивільної конвенції про боротьбу з корупцією» від 16 березня 2005 р. № 2476-IV). URL: https://zakon.rada.gov.ua/laws/ show/994_102\#Text.

8. Конвенція Організації Об'єднаних Націй проти корупції від 31 жовтня 2003 р. (ратифікована згідно із Законом України «Про ратифікацію Конвенції Організації Об'єднаних Націй проти корупції» від 18 жовтня 2006 року № 251-V). Відомості Верховної Ради України (BBP), 2007, № 49. URL: https:// zakon.rada.gov.ua/laws/show/995_c16\#Text.

9. Кримінальна конвенція про боротьбу з корупцією № ETS173 від 27 січня 1999 р. (ратифікована згідно із Законом України «Про ратифікацію Кримінальної конвенції про боротьбу з корупцією» від 18 жовтня 2006 р. № 252-V). Відомості Верховної Ради України (ВBP), 2007, № 47-48. URL: https:// zakon.rada.gov.ua/laws/show/994_101\#Text.

10. Додатковий протокол до Кримінальної конвенції про боротьбу з корупцією від 15 травня 2003 р. № ETS 191 (ратифікована згідно із Законом України «Про ратифікацію Додаткового протоколу до Кримінальної конвенції про боротьбу з корупцією» від 18 жовтня 2006 р. № 253-V). URL: https:// zakon.rada.gov.ua/laws/show/994_172\#Text. 
11. Кофман Б.Я. Міжнародні виборчі стандарти та їх імплементація в законодавство України : дис. ... канд. юрид. наук : спец. : 12.00.02 «Конституційне право; муніципальне право». Маріуполь, 2012. С. 7-8, 16.

12. Про ратифікацію Угоди про партнерство і співробітництво між Україною і Європейськими Співтовариствами та їх державами-членами : Закон України від 10. 11. 1994 р. № 237/94-ВР. Відомості Верховної Ради України. 1994. № 46. Ст. 415.

13. Lobbying in a democratic society (European Code of conduct on lobbying) : Report Committee on
Economic Affairs and Development of 5 June 2009 / Council of Europe Parliamentary Assembly. Strasbourg, 2009. P. 9.

14. Про комітети Верховної Ради України : Закон України від 04.04.1995 р. Відомості Верховної Ради України (ВВР), 1995, № 19, ст. 134. URL: https: / / zakon.rada.gov.ua/laws/main/en/116/95-\%E2\%F0\#Text.

Білик І. В., аспірант кафедри історії і теорії держави та права Запорізького національного університету 